\title{
UPAYA PENGENDALIAN KUALITAS UNTUK MENGURANGI DEFECT PRODUCT PLYWOOD THIN PANEL DENGAN METODE SIX SIGMA DI PT. SUMBER MAS INDAH PLYWOOD
}

\author{
Dwi Tirta Sutrisno Arwanda', Said Salim Dahda ${ }^{2)}$, Elly Ismiyah ${ }^{3)}$ \\ ${ }^{1}$ Mahasiswa Teknik Industri, Fakultas Teknik, Universitas Muhammadiyah Gresik \\ ${ }^{2,3}$ Dosen Teknik Industri, Fakultas Teknik, Universitas Muhammadiyah Gresik \\ Jl. Sumatra No. 101 GKB -Gresik 61121 \\ e-mali:dwitirta234@gmail.com
}

\begin{abstract}
ABSTRAK
PT. Sumber Mas Indah Plywood adalah perusahaan yang bergerak dibidang Manufacturing kayu lapis, pada periode September 2018 - Februari 2019 product plywood thin panel sering mengalami defect product melebihi batas toleransi. Berdasarkan permasalahan ini Bagaimana Upaya pengendalian kualitas untuk mengurangi defect product plywood thin panel dengan metode six sigma DMAI di PT. Sumber Mas Indah Plywood. Sebagai upaya untuk mengurangi jumlah defect langkah awal perlu dilakukan perhitungan DPMO, Sigma, COPQ, analisis akar penyebab masalah dengan Fishbone, serta FMEA, sehingga akar penyebab meningkat. Jumlah defect diketahui presentase defect rata-rata perbulan $7,31 \%$ melebihi batas toleransi perusahaan yang sebesar $5 \%$. Hasil analisis diketahui jenis defect product plywood thin panel yaitu defect core tumpuk, defect fase/back pressmark, dan defect core renggang, sedangkan nilai DPMO atribut sebesar 24.375 dengan nilai sigma 2,476,serta FMEA diperoleh nilai Risk Priority Number (RPN) tertinggi yaitu 648. Sebagai rekomendasi untuk mengurangi defect salah satunya dilakukan training kepada pekerja serta penjadwalan preventif maintenance.
\end{abstract}

Kata kunci : DMAI, DPMO, sigma, COPQ, fishbone, FMEA

\section{PENDAHULUAN}

Salah satu cara memenangkan persaingan dalam dunia industri di era globalisasi adalah dengan memperhatikan masalah kualitas, kualitas merupakan karakteristik produk atau jasa yang dituntut oleh customer dan diperoleh melalui pengukuran proses serta melakukan perbaikan yang berkelanjutan. Menurut Wignjosoebroto (2003) pengendalian kualitas adalah suatu sistem verifikasi dan perawatan dari suatu tingkatan kualitas produk atau proses yang dikehendaki dengan cara perencanaan yang seksama, pemakaian peralatan yang sesuai, inspeksi yang terus menerus, serta tindakan korektif bilamana diperlukan. PT. Sumber Mas Indah Plywood adalah perusahaan yang bergerak dibidang Manufacturing kayu lapis, banyak jenis produksi yang dihasilkan diantaranya adalah Plywood, LVL, Polyster dan Lumbercore. Salah satu jenis Produk utamanya adalah Plywood. Dari berbagai jenis produk Plywood tersebut yang paling banyak Defect adalah produk Thin Panel.

Tabel 1. Data Produksi dan Jenis Defect Produk Thin Panel pada bulan September 2018 Februari 2019

\begin{tabular}{|c|c|c|c|c|c|c|}
\hline \multirow[b]{2}{*}{ Bdan } & \multirow[b]{2}{*}{$\begin{array}{c}\text { Total } \\
\text { Moldiksi tralan }\end{array}$} & \multicolumn{3}{|c|}{ Jenus Deffect (RCS) } & \multirow[b]{2}{*}{ T/Defort/Bin } & \multirow[b]{2}{*}{ "ispefect } \\
\hline & & $\begin{array}{l}\text { Core } \\
\text { Tempuk }\end{array}$ & $\begin{array}{l}\text { Pae bark } \\
\text { Prosimark }\end{array}$ & $\begin{array}{l}\text { Cose } \\
\text { Rerarang }\end{array}$ & & \\
\hline $\operatorname{Seg}: 18$ & 194.48? & 7.716 & 2824 & 1365 & 11905 & 612 \\
\hline act 11 & 197.642 & 7.177 & 3.304 & 1.701 & 12182 & 8.16 \\
\hline Ner-18 & $159.18 ?$ & 6.813 & 3.021 & 2015 & 11449 & $\mathrm{~T}, 44$ \\
\hline Dec-18 & 164845 & 6331 & 3.141 & 2889 & 12301 & 7.46 \\
\hline $\ln -19$ & 208.185 & 9.62 & +192 & 4511 & 16375 & 9.04 \\
\hline Iob-19 & 193.54 & $8.72 \mathrm{t}$ & 2890 & 3239 & 14990 & 7.04 \\
\hline
\end{tabular}

Dengan melihat Tabel 1. Menunjukkan bahwa persentase defect yang terjadi selama 6 bulan 
dengan menggunakan type lem WBP.

Berdasarkan tabel 1. presentase defect terbesar di bulan Januari yaitu $9,04 \%$.

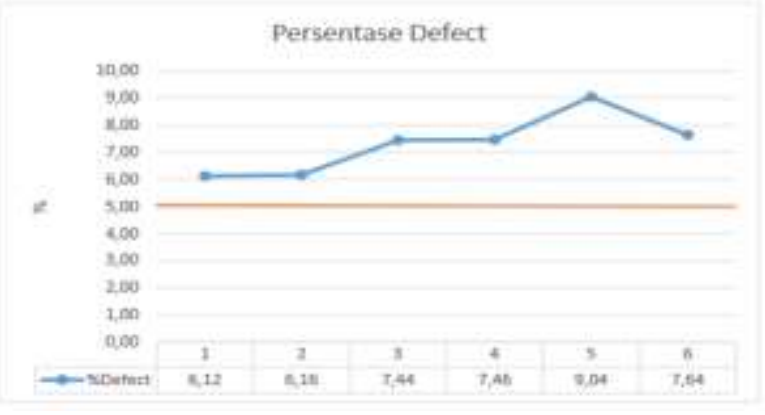

Gambar 1. Grafik Persentase Defect pada produk Thin Panel

Dari gambar 1. bisa dilihat presentase defect pada produk Plywood jenis Thin Panel dinilai cukup tinggi maka perlu dianalisis penyebab - penyebab terjadinya defect. Perusahaan mengharapkan produk dengan kualitas ovl (grade terbaik), tetapi pada praktek di lapangan/proses produksi masih banyak sekali ditemukan cacat/Defect yaitu masih lebih dari 5\% yang diharapkan perusahaan sehingga harapan perusahaan yang menerapkan standart OVL minimal 95\% dan defect maksimal $5 \%$ masih belum terwujud. Untuk Standar ekspor ke negara jepang ataupun Eropa punya Standar OVL yaitu $90 \%$ dan $10 \%$ masuk grade 2 yaitu defect.

Dari data setahun yang lalu (September 2018Februari 2019) masih banyak didapatkan hasil defect yang masih diatas 5\% (defect Max 5\%), juga pada data historis tersebut defect terbanyak merupakan defect jenis Face/Bcak Pressmark, Core Tumpuk, dan Core Renggang dimana ketiga defect ini merupakan defect yang menyumbang persentase terbanyak dari total semua jenis defect, hal ini dapat membuat status produk yang semula OVL menjadi UTY (penurunan grade) dikarenakan defect yang terjadi pada produk tersebut. Berdasarkan permasalahan yang terjadi pada proses produksi thin panel, dibutuhkan penelitian untuk melakukan perbaikan. Salah satu cara yang dapat dilakukan adalah dengan pendekatan six sigma. Six sigma adalah metode yang sangat tepat digunakan di dalam industri yang memiliki masalah kualitas dengan melakukan/menggunakan seperangkat tools mengidentifikasi (define), mengukur (measure), menganalisis (analyze), memperbaiki (improve) dan mengendalikan (control) sumber variasi dalam proses (Gaspersz, 2007).

Tujuan dari penelitian ini adalah mengidentifikasi faktor-faktor apa yang menyebabkan terjadinya cacat (defect) pada produk thin panel, menghitung nilai COPQ, Defect per million opportunity, Sigma. Dan memberikan usulan rancangan perbaikan untuk mengurangi produk defect.

\section{A. Definisi Kualitas}

Kualitas atau mutu adalah tingkat baik buruknya atau taraf atau derajat sesuatu. Istilah ini banyak digunakan dalam suatu bisnis, rekayasa dan manufaktur dalam kaitannya dengan teknik dan konsep untuk memperbaiki kualitas produk atau jasa yang dihasilkan, seperti Six Sigma, TQM, Kaizen, dll

\section{B. Pengertian Pengendalian Kualitas}

Menurut Assauri (1998) pengendalian mutu merupakan usaha untuk mempertahankan mutu atau kualitas dari produk yang dihasikan, agar sesuai dengan spesifikasi produk yang telah ditetapkan berdasarkan kebijaksanaan pimpinan Assauri perusahaan.

Tujuan dari pengendalian kualitas adalah untuk mengetahui sampai sejauh mana proses dan hasil produk yang dibuat sesuai dengan standar yang sudah ditetapkan oleh perusahaan.

\section{Six Sigma}

Six Sigma menurut Peter S Pande (2000), merupakan sebuah sistem yang kompresif dan fleksibel untuk mencapai, mempertahankan, dan memaksimalkan sukses bisnis. Six Sigma secara unit dikendalikan oleh pemahaman yang kuat terhadap kebutuhan pelanggan, pemakaian yang 
disiplin terhadap fakta, data dan analisis statistic dan perhatian yang cermat untuk mengelola, memperbaiki dan menanamkan kembali proses bisnis.

Berikut adalah beberapa istilah yang biasa digunakan dan akan mempermudah dalam pemahaman six sigma antara lain : (Gaspersz,2001).

1. Critical To Quality (CTQ), merupakan atribut-atribut yang sangat penting untuk diperhatikan karena berkaitan langsung dengan kebutuhan dan kepuasan customer.

2. Defect, merupakan kegagalan untuk memberikan apa yang diinginkan oleh customer.

3. Defect per unit (DPU), merupakan ukuran kemungkinan terjadinya cacat atau kegagalan per unit, dihitung dengan persamaan :

$$
D P U=\frac{\text { Banyaknya Defect }}{\text { Banyaknya Unit }}
$$

4. Defect per oppoturnity (DPO), merupakan ukuran kegagalan yang dihitung dalam program peningkatan kualitas six sigma yang menunjukkan banyaknya cacat atau kegagalan per satu kesempatan.

$D P O=\frac{\text { Banyaknya Defect }}{\text { Banyaknya unit x opportunity }}$

5. Defect per million opportunity (DPMO), merupakan kegagalan dalam program peningkatan kualitas six sigma, yang menunjukkan kegagalan per sejuta kesempatan. DPMO dapat dihitung dengan rumus :

DPMO $=$ DPO $\times 1.000 .000$ Pemahaman terhadap DPMO ini sangat penting dalam pengukuran keberhasilan aplikasi program peningkatan kualitas six sigma.

6. Process capability, merupakan keampuan proses untuk memproduksi atau menyerahkan output sesuai dengan ekspektasi dan kebutuhan customer.
7. Variation, merupakan apa yang customer lihat dan rasakan dalam proses transaksi antara supplier dan customer itu. Semakin kecil variasi akan semakin disukai karena menunjukkan konsistensi dalam kualitas.

8. Stable oOperation, jaminan konsistensi proses yang dapat di perkirakan dan dikendalikan guna meningkatkan apa yang customer lihat dan rasakan serta meningkatkan ekspektasi dan kebutuhan customer.

9. Design for six sigma, merupakan suatu design untuk memenuhi kebutuhan customer dan kemampuan proses.

Pendekatan pengendalian proses 6-sigma Motorola mengijinkan adanya pergeseran nilai target rata-rata (mean) setiap CTQ individual dari proses industri sebesar $\pm 1,5$-sigma (baca : plus/minus 1,5-sigma, sehingga akan menghasilkan 3,4 DPMO (Defect Per Million Opportunity-kegagalan per sejuta kesempatan). Proses 6-sigma dengan distribusi normal bergeser 1,5-sigma.

Tabel 2. Nilai Kapabilitas Proses pada berbagai pencapaian tingkat Sigma untuk Data Variabel

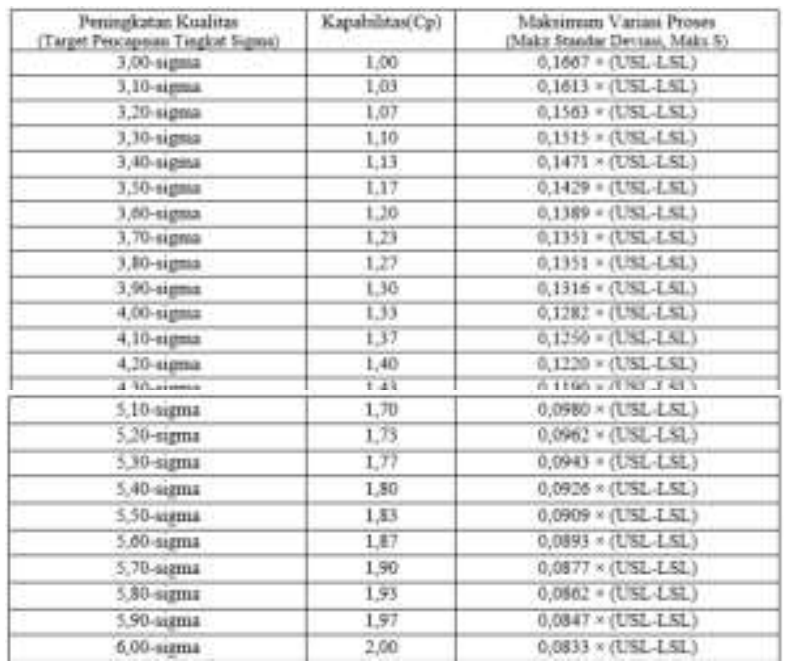

Sumber : Gaspersz (2001) 
Perlu dicacat dan dipahami bahwa konsep Six Sigma Motorola dengan pergeseran nilai target (nilai rata-rata) yang diijinkan sebesar 1,5-sigma (1,5-sigma (1,5 x maksimum standar deviasi) adalah berbeda dengan konsep Six Sigma dalam distribusi normal yang tidak mengijinkan pergeseran dalam nilai rata-rata.

\section{Tahapan Peningkatan Kualitas Six Sigma}

Menurut Pande (2003) dalam Six Sigma Way, menggunakan dan merujuk pada siklus lima-fase yang makin umum dalam organisasiorganisasi Six Sigma yaitu DMAIC singkatan dari Define (tentukan), Measure (ukur), Analyze (analisa), Improve (tingkatkan), dan Control (kendalikan). DMAIC diterapkan baik pada perbaikan proses maupun pada perancangan ulang proses.

\section{Define}

Define merupakan langkah operasional pertama dalam program penigkatan kualitas Six Sigma. Pada tahapan ini kita perlu mengidentifikasi beberapa hal yang terkait dengan kriteria pemilihan proyek Six Sigma, peran dan tanggung jawab dari orang-orang yang akan terlibat dalam proyek Six Sigma (Gaspersz, 2002).

\section{Measure}

Measure merupakan langkah operasional kedua dalam program-program peningkatan kualitas Six Sigma. Terdapat tiga hal pokok yang harus dilakukan dalam tahapan measure yaitu :

a. Memilih atau menentukan karakteristik kualitas (CTQ) kunci yang berhubungan langsung dengan kebutuhan spesifik dari customer. b. Mengembangkan suatu rencana pengumpulan data melalui pengukuran yang dapat dilakukan pada tingkat proses, output, atau outcome.

\section{Analyze}

Analyze (analisa) merupakan langkah ketiga dalam program peningkatan kualitas Six Sigma, pada tahapan ini dilakukan beberapa hal :

- Menentukan stabilitas dan kemampuan dari proses.

$$
C p=\frac{U S L-L S L}{6 \text { standar deviasi }}
$$

- Menentukan target-target kinerja dari karakteristik kualitas kunci (CTQ) yang akan ditingkatkan dalam proyek Six Sigma.

- Mengidentifikasi sumber-sumber akan penyebab kecacatan dan kegagalan.

\section{Improve}

Pada dasarnya rencana-rencana tindakan (action plans) akan mendeskripsikan tentang alokasi sumber-sumber daya serta prioritas dan alternatif yang dilakukan dalam implementasi dari rencana itu.

\section{Control}

Control merupakan tahapan terakhir dalam proyek peningkatan kualitas Six Sigma. Tim Six Sigma kepada pemilik atau penanggung jawab proses, yang berarti proyek Six Sigma berakhir pada tahapan ini.

\section{E. Failure Mode and Effects Analysis (FMEA)}

FMEA atau analisis mode kegagalan dan efek adalah suatu prosedur terstruktur 
untuk mengidentifikasi dan mencegah sebanyak mungkin mode kegagalan. Langkahlangkah dalam membuat FMEA adalah sebagai berikut :

1. Mengidentifikasi proses atau produk/jasa

2. Mendaftarkan masalah-masalah potensial yang dapat muncul, efek dari masalahmasalah potensial tersebut dan penyebabnya.

3. Menilai masalah untuk keparahan (severity), probabilitas kejadian (occurance) dan detektabilitas (detection).

4. Menghitung Risk Priority Number atau RPN yang rumusnya adalah dengan mengalikan ketiga variabel dalam poin 3 diatas dan menentukan rencana solusisolusi prioritas yang harus dilakukan. RPN $=\mathrm{S} \times \mathrm{O} \times \mathrm{D}$.

\section{KERANGKA PENELITIAN}

Dalam Penelitian ini langkah awal yang dilakukan adalah melakukan observasi lapangan untuk mengidentifikasi permasalahan yang terjadi, setelah diketahui permasalahan yang terjadi dilakukan perumusan masalah dan penentuan tujuan penelitian, dalam penelitian ini metode yang digunakan adalah Six Sigma dengan penerapan siklus DMAI. Lebih jelas kerangka pemikiran penelitian dapat dilihat pada gambar

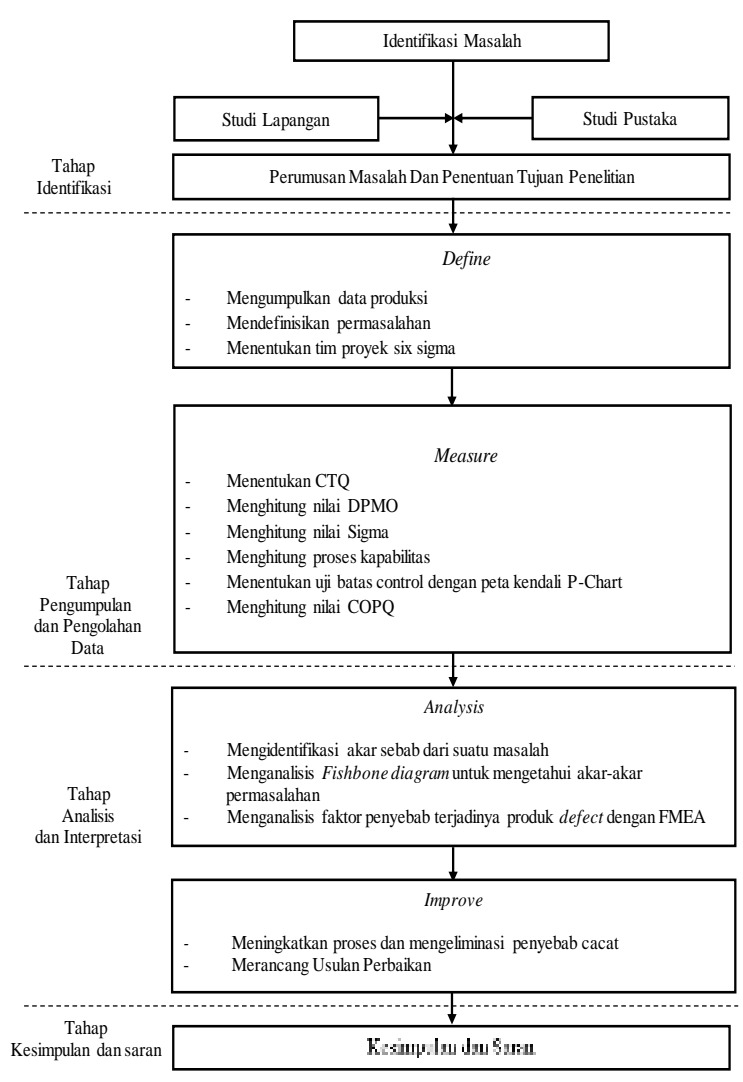

Gambar 2. Kerangka Penelitian

\section{HASIL DAN PEMBAHASAN}

\section{A. Tahap Define}

Dalam tahap define ini akan dijelaskan tentang data produksi dan tim yang menangani proyek six sigma dalam penelitian ini.

\section{Data Produksi}

Data defect product plywood thin panel pada bulan September 2018 s.d Februari 2019 dengan menggunakan type lem WBP.

\section{Tim Proyek Six Sigma}

Tim proyek ini terdiri dari beberapa kelompok dengan peran generik sesuai dengan job masingmasing. Adapun tim proyek ini terdiri dari :

1. Ketua tim proyek six sigma

2. Kabag QC

3. Supervisor QC

4. Kabag Produksi

5. Operator Produksi 


\section{B. Tahap Measure}

\section{Penentuan Critical to Quality (CTQ)}

Adapun terdapat 3 titik Critical to Quality (CTQ) dari produk defect plywood thin panel yang bersumber dari data Quality Control PT. Sumber Mas Indah Plywood, Sebagai berikut :

1. Core Tumpuk

2. Fase/back Pressmark

3. Core Renggang

\section{Diagram Pareto}

Untuk mengetahui jenis defect yang dominan dengan menggunakan diagram pareto.

3. Perhitungan Nilai Defect per Million Opportunity (DPMO)

Berdasarkan data yang diperoleh untuk mencari nilai DPMO data atribut, sebagai berikut :

- Total Cacat (Defect atribut = core tumpuk, fase/back pressmark, core renggang $=81.400$ pcs

- $\quad$ Total Produksi $=1.112 .900$ pcs

- $\quad$ Jumlah Kesempatan Potensi Kecacatan $=3$

$\mathrm{DPMO}=$

$\frac{\sum \text { Defect atau kegagalan yang ditemukan }}{\sum \text { Produksi } x \sum \text { Kesempatan Potensial Kecacatan }} \times$ 1.000 .000

$\mathrm{DPMO}=\frac{81.400}{\sum 1.62 .900 \times 3} \times 1.000 .000$

$\mathrm{DPMO}=24.381$

8.

Berdasarkan perhitungan diatas bias dilihat bahwa dalam 1.000 .000 pes terdapat 24.381 defect atribut yang bisa dihasilkan. untuk mencari nilai sigms dapat menggunakan rumus excel sigma, sebagai berikut :

Rumus Sigma $=$ NORMSINV $((1000000-$ DPMO $) / 1000000)+1,5$ $=$ NORMSINV $((1000000-24.381 / 1000000)+1,5$

$$
=3,47 \text { dibulatkan menjadi }=3,5
$$

Berdasarkan perhitungan diatas bisa diketahui nilai sigma yaitu sebesar 3,5

\section{Uji Batas Kontrol Tingkat Defect Product Plywood Thin Panel dengan P-Chart}

Sebelum data sampel diuji, maka ditentukan dahulu jumlah sampel yang akan diambil. Berdasarkan tabel krejcie dan morgan bahwa populasi $\geq 100.000$ pcs dengan tingkat keyakinan penelitian 95\% dan tingkat kesalahan 5\% maka jumlah sampel yang diambil minimal sebanyak 382. Teknik pengumpulan dilakukan dengan sampling sistematis. Pengambilan sampling dilakukan per hari sebanyak 39 pcs 10x pada tanggal 1-10 juni 2019.

\section{Kapabilitas Proses Berdasarkan Data Atribut (P)}

Untuk mendapatkan nilai kapabilitas proses untuk data atribut adalah dengan rumus sebagai berikut :

$$
\mathrm{Cp}=1-\bar{p}
$$

Dimana $: \mathrm{Cp}=$ Indeks kapabilitas proses

$$
\bar{p}=\text { rata-rata proporsi cacat }
$$

\section{Perhitungan Nilai Cost Of Poor Quality (COPQ)}

Biaya repair 1 bulan yaitu :

- 1 Box $=82.000,8$ box isi catter per bulan = 656.000,-

-1 roll $=25.130,20$ roll gum tape $16 \mathrm{~mm}=$ 502.600,-

Biaya tenaga kerja ini sesuai dengan kebijakan Perusahaan PT.Sumber Mas Indah Plywood yaitu : 
- Tenaga kerja dalam proses repair adalah harian lepas (borongan) dengan sistem gaji per pcs Rp.506,-

Tabel 3. Biaya pengerjaan ulang (Reproses)

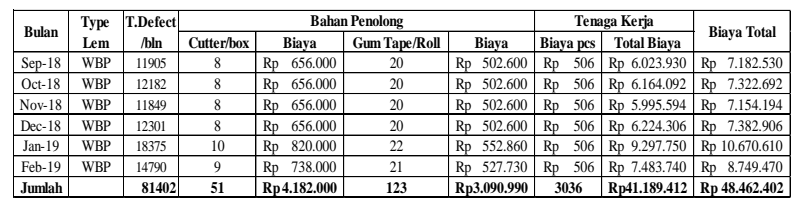

Perhitungan bulan September 2018

Diketahui :

Defect Product : 11.905

-Box Catter : 8 Box $\times$ Rp. $82.000=$ Rp. 656.000

-Roll Gum Tape : 20 roll $\times$ Rp. $25.130=$ Rp. 502.600

-Tenaga Kerja $\quad: 11.905 \times$ Rp. 506,- = Rp. 6.023.930

-Jadi total biaya pada bulan September = Biaya

Box Catter + Biaya Roll Gum Tape + Tenaga Kerja

$=$ Rp. $656.000+R p \cdot 502.600+R p \cdot 6.023 .930$

$=$ Rp. 7.182 .530

Pengerjaan ulang (reproses) oleh tenaga kerja :

1. Proses solasi gum tape dari produk plywood thin panel dengan menutup veneer yang sobek atau berlubang.

2. Proses meratakan atau merapikan veneer yang tidak presisi dengan menggunakan catter.

Dapat diketahui bahwa cost of poor quality untuk biaya repair akibat defect product plywood thin panel pada bulan September-Februari 2019 sebanyak 81.402 pcs dengan menghabiskan 48 box catter $=$ Rp. 3.936.000,- dan 120 roll gum tape $=$
Rp. 3.015.600,- dan biaya tenaga kerja reproses $=$ 41.189.412,-. Jadi total biaya kerugian dalam proses repair $=\mathrm{Rp} .48 .462 .402,-$.

\section{Tahap Analyze}

1. Diagram Fishbone

\section{A. Kategori defect core tumpuk}

1. Personnel (Manusia)

Pekerja tidak kontrol secara continue, kurang disiplin dalam bekerja, kurang safety dalam bekerja sehingga terjadi kecelakaan kerja.

2. Material (Bahan Baku)

Bahan baku yang kurang bagus dikarenakan kayu terlalu lama direndam air.

3. Environment (Lingkungan)

House keeping yang tidak diterapkan maksudnya kurangnya tempat penyimpanan veneer hasil produksi yang berlebih dan sampah veneer dibiarkan menumpuk berlebihan. Area kerja yang kotor disekitar mesin plywood sehingga tidak nyaman bagi pekerja.

4. Machines (Mesin) Kurangnya inspeksi pada mesin sehingga mesin sering mengalami masalah atau troubel, kurangnya perawatan mesin, Hotpress yang tidak stabil sehingga menyebabkan defect.

5. Methods (Metode) SOP yang tidak diterapkan.

\section{Kategori defect pressmark}

1. Personnel (Manusia)

Pekerja kurang teliti dalam melakukan pekerjaan yang dijalankan, kurang displin dalam jam bekerja sehingga waktu terbuang sia-sia , kurangnya safety sehingga mengakibatkan kecelakaan kerja.

2. Material (Bahan Baku) 
Bahan baku kurang bagus dikarenakan jenis kayu yang diolah sudah terlalu lama direndam air.

3. Environment (Lingkungan)

House keeping yang tidak diterapkan maksudnya kurangnya tempat penyimpanan veneer hasil produksi yang berlebih dan sampah veneer dibiarkan menumpuk berlebihan. Area kerja yang kotor disekitar mesin plywood sehingga tidak nyaman bagi pekerja.

4. Machines (Mesin)

Kurangnya inspeksi pada mesin sehingga mesin sering mengalami masalah atau troubel, kurangnya perawatan mesin, Hotpress yang tidak stabil sehingga menyebabkan defect.

5. Method (Metode)

SOP yang tidak diterapkan dan peralatan yang usang.

\section{Kategori defect core renggang}

1. Personnel (Manusia)

Pekerja tidak kontrol secara continue, kurang disiplin dalam bekerja, kurang safety dalam bekerja sehingga terjadi kecelakaan kerja.

2. Material (Bahan Baku)

Bahan baku yang kurang bagus dikarenakan kayu terlalu lama direndam air.

3. Environment (Lingkungan)

House keeping yang tidak diterapkan maksudnya kurangnya tempat penyimpanan veneer hasil produksi yang berlebih dan sampah veneer dibiarkan menumpuk berlebihan. Area kerja yang kotor disekitar mesin plywood sehingga tidak nyaman bagi pekerja.

4. Machines (Mesin)

Kurangnya inspeksi pada mesin sehingga mesin sering mengalami masalah atau troubel, kurangnya perawatan mesin, Hotpress yang tidak stabil sehingga menyebabkan defect.

5. Methods (Metode)

SOP yang tidak diterapkan.

\section{Failure Mode and Effect Analysis (FMEA)}

FMEA dibuat berdasarkan hasil diskusi dengan Kabag QC, Supervisior QC, Kabag Produksi dan Operator Produksi di perusahaan PT. Sumber Mas Indah Plywood dengan diambil nilai rata-rata tiap item. Kolom deskripsi proses menunjukkan proses terjadinya kegagalan proses, kolom mode kegagalan menunjukkan jenis kegagalan yang terjadi, kolom efek kegagalan menunjukkan akibat yang ditimbulkan jika terjadi mode kegagalan. Berikut merupakan hasil dari FMEA. 
Tabel 4. Tabel FMEA

\begin{tabular}{|c|c|c|c|c|c|c|c|c|}
\hline Failure Effect & Failure & $\mathrm{S}$ & Failure Mode & O & Control & D & RPN & Priority \\
\hline \multirow{10}{*}{ Defect Core Tumpuk } & $\begin{array}{l}\text { House keeping tidak } \\
\text { diterapkan }\end{array}$ & 7 & $\begin{array}{l}\text { Kurangnya } \\
\text { memperhatikan } \\
\text { lingkungan kerja }\end{array}$ & 6 & $\begin{array}{l}\text { pengarahan terhadap pekerja } \\
\text { agar menerapkan } 5 \mathrm{R} \text { sebelum } \\
\text { bekerja }\end{array}$ & 7 & 294 & 9 \\
\hline & Area kerja kotor & 4 & $\begin{array}{l}\text { kurangnya } \\
\text { memperhatikan area } \\
\text { kerja yang kotor }\end{array}$ & 6 & $\begin{array}{l}\text { pengarahan terhadap pekerja } \\
\text { jika waktu kerja ada yang kotor } \\
\text { sebaiknya dibersihkan dulu }\end{array}$ & 5 & 120 & 17 \\
\hline & Bahan baku kurang bagus & 8 & $\begin{array}{l}\text { jenis kayu yang diolah } \\
\text { sudah terlalu lama } \\
\text { direndam air }\end{array}$ & 9 & $\begin{array}{l}\text { Melakukan pemilihan mix kayu } \\
\text { log tidak terlalu banyak kayu } \\
\text { yang jeleknya }\end{array}$ & 8 & 576 & 2 \\
\hline & $\begin{array}{l}\text { Pekerja tidak kontrol } \\
\text { secara continue }\end{array}$ & 7 & $\begin{array}{l}\text { kurangnya kontrol } \\
\text { terhadap mesin yang di } \\
\text { jalankan }\end{array}$ & 9 & $\begin{array}{l}\text { melakukan kontrol secara } \\
\text { continue di fokuskan }\end{array}$ & 8 & 504 & 4 \\
\hline & Kurang disiplin & 5 & $\begin{array}{l}\text { dikarenakan tidak } \\
\text { adanya brefing } \\
\text { sebelum bekerja }\end{array}$ & 6 & $\begin{array}{l}\text { memberikan himbauan agar } \\
\text { pekerja lebih ditingkatkan } \\
\text { kedisplinan dalam bekerja }\end{array}$ & 8 & 240 & 12 \\
\hline & Kurang safety & 8 & $\begin{array}{l}\text { kurangnya pemahaman } \\
\text { tentang } \mathrm{K} 3\end{array}$ & 7 & $\begin{array}{l}\text { memberikan himbauan agar } \\
\text { safety lebih diutamakan supaya } \\
\text { tidak terjadi kecelakaan kerja }\end{array}$ & 7 & 392 & 6 \\
\hline & SOP tidak diterapkan & 9 & $\begin{array}{l}\text { kurangnya training } \\
\text { terhadap pekerja }\end{array}$ & 8 & $\begin{array}{l}\text { memberikan himbauan agar } \\
\text { bekerja sesuai SOP }\end{array}$ & 9 & 648 & 1 \\
\hline & $\begin{array}{l}\text { Mesin Hotpress tidak } \\
\text { stabil }\end{array}$ & 6 & $\begin{array}{l}\text { Kurangnya corrective } \\
\text { maintanance }\end{array}$ & 6 & $\begin{array}{l}\text { melakukan pengecekan dan } \\
\text { perawatan mesin hotpress secara } \\
\text { continue }\end{array}$ & 6 & 216 & 13 \\
\hline & Kurang perawatan & 4 & $\begin{array}{l}\text { perawatan mesin yang } \\
\text { tidak continue }\end{array}$ & 6 & $\begin{array}{l}\text { melakukan perawatan mesin } \\
\text { secara continue }\end{array}$ & 5 & 120 & 17 \\
\hline & Inspeksi & 7 & $\begin{array}{l}\text { pengecekan yang } \\
\text { kurang dilakukan oleh } \\
\text { pekerja }\end{array}$ & 7 & pengecekan lebih ditingkatkan & 7 & 343 & 7 \\
\hline \multirow{3}{*}{ Defect Pressmark } & $\begin{array}{l}\text { House keeping tidak } \\
\text { diterapkan }\end{array}$ & 7 & $\begin{array}{l}\text { Kurangnya } \\
\text { memperhatikan } \\
\text { lingkungan kerja }\end{array}$ & 7 & $\begin{array}{l}\text { pengarahan terhadap pekerja } \\
\text { agar menerapkan } 5 R \text { sebelum } \\
\text { bekerja }\end{array}$ & 7 & 343 & 7 \\
\hline & Area kerja kotor & 6 & $\begin{array}{l}\text { kurangnya } \\
\text { memperhatikan area } \\
\text { kerja yang kotor }\end{array}$ & 6 & $\begin{array}{l}\text { pengarahan terhadap pekerja } \\
\text { jika waktu kerja ada yang kotor } \\
\text { sebaiknya dibersihkan dulu }\end{array}$ & 7 & 252 & 11 \\
\hline & Bahan baku kurang bagus & 8 & $\begin{array}{l}\text { jenis kayu yang diolah } \\
\text { sudah terlalu lama } \\
\text { direndam air }\end{array}$ & 9 & $\begin{array}{l}\text { Melakukan pemilihan mix kayu } \\
\text { log tidak terlalu banyak kayu } \\
\text { yang jeleknya }\end{array}$ & 8 & 576 & 2 \\
\hline
\end{tabular}




\begin{tabular}{|c|c|c|c|c|c|c|c|c|}
\hline & Pekerja kurang teliti & 9 & $\begin{array}{l}\text { kurangnya kontrol } \\
\text { pada saat bekerja }\end{array}$ & 9 & $\begin{array}{l}\text { melakukan kontrol secara } \\
\text { continue di fokuskan }\end{array}$ & 8 & 648 & 1 \\
\hline & Kurang displin & 5 & $\begin{array}{l}\text { dikarenakan tidak } \\
\text { adanya brefing } \\
\text { sebelum bekerja }\end{array}$ & 8 & $\begin{array}{l}\text { memberikan himbauan agar } \\
\text { pekerja lebih ditingkatkan } \\
\text { kedisplinan dalam bekerja }\end{array}$ & 7 & 280 & 10 \\
\hline & Peralatan Usang & 7 & masa pakai telah habis & 7 & $\begin{array}{l}\text { melakukan pergantian alat jika } \\
\text { sudah tidak layak digunakan }\end{array}$ & 7 & 343 & 7 \\
\hline & SOP tidak diterapkan & 7 & $\begin{array}{l}\text { kurangnya training } \\
\text { terhadap pekerja }\end{array}$ & 7 & $\begin{array}{l}\text { memberikan himbauan agar } \\
\text { bekerja sesuai SOP }\end{array}$ & 7 & 343 & 7 \\
\hline & Mesin kotor & 6 & $\begin{array}{l}\text { kurangnya perawatan } \\
\text { dari pekerja dibagian } \\
\text { thin panel }\end{array}$ & 6 & $\begin{array}{l}\text { dibersihkan agar tidak cepat } \\
\text { rusak }\end{array}$ & 7 & 252 & 11 \\
\hline & Kurang perawatan & 5 & $\begin{array}{l}\text { perawatan mesin yang } \\
\text { tidak continue }\end{array}$ & 6 & $\begin{array}{l}\text { melakukan perawatan mesin } \\
\text { secara continue }\end{array}$ & 6 & 180 & 14 \\
\hline & Inspeksi & 6 & $\begin{array}{l}\text { pengecekan yang } \\
\text { kurang dilakukan oleh } \\
\text { pekerja }\end{array}$ & 6 & pengecekan lebih ditingkatkan & 6 & 216 & 13 \\
\hline $\begin{array}{l}\text { Defect } \quad \text { Core } \\
\text { Renggang }\end{array}$ & $\begin{array}{l}\text { House keeping tidak } \\
\text { diterapkan }\end{array}$ & 7 & $\begin{array}{l}\text { Kurangnya } \\
\text { memperhatikan } \\
\text { lingkungan kerja }\end{array}$ & 7 & $\begin{array}{l}\text { pengarahan terhadap pekerja } \\
\text { agar menerapkan } 5 \mathrm{R} \text { sebelum } \\
\text { bekerja }\end{array}$ & 7 & 343 & 7 \\
\hline & Area kerja kotor & 5 & $\begin{array}{l}\text { kurangnya } \\
\text { memperhatikan area } \\
\text { kerja yang kotor }\end{array}$ & 6 & $\begin{array}{l}\text { pengarahan terhadap pekerja } \\
\text { jika waktu kerja ada yang kotor } \\
\text { sebaiknya dibersihkan dulu }\end{array}$ & 5 & 150 & 15 \\
\hline & Bahan baku kurang bagus & 8 & $\begin{array}{l}\text { jenis kayu yang diolah } \\
\text { sudah terlalu lama } \\
\text { direndam air }\end{array}$ & 9 & $\begin{array}{l}\text { Melakukan pemilihan mix kayu } \\
\text { log tidak terlalu banyak kayu } \\
\text { yang jeleknya }\end{array}$ & 9 & 648 & 1 \\
\hline & $\begin{array}{l}\text { Pekerja tidak kontrol } \\
\text { secara continue }\end{array}$ & 7 & $\begin{array}{l}\text { kurangnya kontrol } \\
\text { terhadap mesin yang di } \\
\text { jalankan }\end{array}$ & 9 & $\begin{array}{l}\text { melakukan kontrol secara } \\
\text { continue di fokuskan }\end{array}$ & 9 & 567 & 3 \\
\hline & Kurang disiplin & 6 & $\begin{array}{l}\text { dikarenakan tidak } \\
\text { adanya brefing } \\
\text { sebelum bekerja }\end{array}$ & 7 & $\begin{array}{l}\text { memberikan himbauan agar } \\
\text { pekerja lebih ditingkatkan } \\
\text { kedisplinan dalam bekerja }\end{array}$ & 8 & 336 & 8 \\
\hline & Kurang safety & 8 & $\begin{array}{l}\text { kurangnya pemahaman } \\
\text { tentang } \mathrm{K} 3\end{array}$ & 7 & $\begin{array}{l}\text { memberikan himbauan agar } \\
\text { safety lebih diutamakan supaya } \\
\text { tidak terjadi kecelakaan kerja }\end{array}$ & 8 & 448 & 5 \\
\hline & SOP tidak diterapkan & 8 & $\begin{array}{l}\text { kurangnya training } \\
\text { terhadap pekerja }\end{array}$ & 7 & $\begin{array}{l}\text { memberikan himbauan agar } \\
\text { bekerja sesuai SOP }\end{array}$ & 8 & 448 & 5 \\
\hline & $\begin{array}{l}\text { Mesin Hotpress tidak } \\
\text { stabil }\end{array}$ & 6 & $\begin{array}{l}\text { Kurangnya corrective } \\
\text { maintanance }\end{array}$ & 6 & $\begin{array}{l}\text { melakukan pengecekan dan } \\
\text { perawatan mesin hotpress secara } \\
\text { continue }\end{array}$ & 6 & 216 & 13 \\
\hline & Kurang perawatan & 4 & $\begin{array}{l}\text { perawatan mesin yang } \\
\text { tidak continue }\end{array}$ & 6 & $\begin{array}{l}\text { melakukan perawatan mesin } \\
\text { secara continue }\end{array}$ & 6 & 144 & 16 \\
\hline & Inspeksi & 6 & $\begin{array}{l}\text { pengecekan yang } \\
\text { kurang dilakukan oleh } \\
\text { pekerja }\end{array}$ & 6 & pengecekan lebih ditingkatkan & 7 & 252 & 11 \\
\hline
\end{tabular}




\section{Improve}

\section{Usulan rancangan perbaikan untuk defect core tumpuk}

Adapun usulan perbaikan untuk defect core tumpuk adalah sebagai berikut:

Memberikan training kepada operator produksi tentang Standard Operational Procedure (SOP) setiap 1 bulan sekali atau mengingatkan pada awal shift sebelum bekerja tentang Standard Operational Procedure (SOP) agar tidak terjadi defect core tumpuk :

a. Penyettingan posisi veneer harus benar dan sejajar pada saat masuk ke thin panel.

b. Perputaran roll standart tidak harus cepat.

c. Suhu mesin tidak terlalu tinggi.

\section{Usulan Rancangan Perbaikan untuk defect pressmark}

Adapun usulan perbaikan untuk defect core tumpuk adalah sebagai berikut: Memberikan training kepada operator produksi tentang Standard Operational Procedure (SOP) setiap 1 bulan sekali atau mengingatkan pada awal shift sebelum bekerja tentang Standard Operational Procedure (SOP) agar tidak terjadi defect pressmark:

a. Harus lebih di kontrol lagi sehingga veneer tidak terlalu lebar dan berlipat.

b. Lebih teliti dalam mengontrol sampah atau kotoran veneer.

c. Papan baja pada cold/hot harus dibersihkan

\section{Usulan rancangan perbaikan untuk defect core renggang}

Adapun usulan perbaikan untuk defect core tumpuk adalah sebagai berikut:

Memberikan training kepada operator produksi tentang Standard Operational Procedure (SOP) setiap 1 bulan sekali atau mengingatkan pada awal shift sebelum bekerja tentang Standard Operational Procedure (SOP) agar tidak terjadi defect core renggang :

a. Pemasangan gum tape lebih teliti agar veneer tidak terlepas.

b. Perputaran roll harus standar atau lambat agar veneer tidak pecah.

c. Penyusunan veneer agar lebih hati-hati supaya tidak pecah.

\section{KESIMPULAN}

Adapun kesimpulan dari hasil penelitian ini, sebagai berikut :

1. Faktor-faktor yang menyebabkan defect product plywood thin panel yaitu

a. Defect core tumpuk

1. Personnel (Manusia)

Pekerja tidak kontrol secara continue, kurang disiplin dalam bekerja, kurang safety dalam bekerja sehingga terjadi kecelakaan kerja.

2. Material (Bahan Baku)

Bahan baku yang kurang bagus dikarenakan kayu terlalu lama direndam air.

3. Environment (Lingkungan)

House keeping yang tidak diterapkan dan area kerja yang kotor sehingga tidak nyaman bagi pekerja.

4. Machines (Mesin) Inspeksi, kurangnya perawatan mesin, Hotpress yang tidak stabil sehingga menyebabkan defect.

5. Methods (Metode)

SOP yang tidak diterapkan. 
3. Defect Fase/Back Pressmark

1. Personnel (Manusia)

Pekerja kurang teliti dalam melakukan pekerjaan yang dijalankan, kurang displin dalam jam bekerja sehingga waktu terbuang sia-sia, kurangnya safety sehingga mengakibatkan kecelakaan kerja.

2. Material (Bahan Baku)

Bahan baku kurang bagus dikarenakan jenis kayu yang diolah sudah terlalu lama direndam air.

3. Environment (Lingkungan)

House keeping yang tidak diterapkan dan area kerja yang kotor sehingga tidak nyaman bagi pekerja.

6. Machines (Mesin)

Inspeksi, kurangnya perawatan yang dilakukan oleh maintenance dan mesin yang kotor tidak dibersihkan.

7. Method (Metode)

SOP yang tidak diterapkan dan peralatan yang usang.

c. Core Renggang

\section{Personnel (Manusia)}

Pekerja tidak kontrol secara continue, kurang disiplin dalam bekerja, kurang safety dalam bekerja sehingga terjadi kecelakaan kerja.

2. Material (Bahan Baku)

Bahan baku yang kurang bagus dikarenakan kayu terlalu lama direndam air.

3. Environment (Lingkungan)

House keeping yang tidak diterapkan dan area kerja yang kotor sehingga tidak nyaman bagi pekerja.

4. Machines (Mesin)
Inspeksi, kurangnya perawatan mesin, Hotpress yang tidak stabil sehingga menyebabkan defect.

5. Methods (Metode)

SOP yang tidak diterapkan.

2. Dalam penelitian ini untuk defect product plywood thin panel bulan September 2018 - Februari 2019 diketahui perhitungan COPQ untuk biaya reproses yaitu sebesar Rp.48.462.402. DPMO data atribut diketahui sebesar 24.381 dengan nilai sigma level 3,5.

3. Berikut adalah usulan dari 3 defect product plywood thin panel yaitu:

a. Usulan rancangan perbaikan untuk defect core tumpuk :

Memberikan training kepada operator produksi tentang Standard Operational Procedure (SOP) setiap 1 bulan sekali atau mengingatkan pada awal shift sebelum bekerja tentang Standard Operational Procedure (SOP) agar tidak terjadi defect core tumpuk :

1. Penyetingan posisi veneer harus benar dan sejajar pada saat masuk ke thin panel.

2. Perputaran roll standart tidak harus cepat.

3. Suhu mesin tidak terlalu tinggi.

b. Usulan Rancangan Perbaikan untuk defect pressmark

Memberikan training kepada operator produksi tentang Standard Operational Procedure (SOP) setiap 1 bulan sekali atau mengingatkan pada awal shift sebelum bekerja tentang Standard Operational Procedure (SOP) agar tidak terjadi defect pressmark: 
1. Harus lebih di kontrol lagi sehingga veneer tidak terlalu lebar dan berlipat.

2. Lebih teliti dalam mengontrol sampah atau kotoran veneer.

3. Papan baja pada cold/hot harus dibersihkan

c. Usulan rancangan perbaikan untuk defect core renggang

Memberikan training kepada operator produksi tentang Standard Operational Procedure (SOP) setiap 1 bulan sekali atau mengingatkan pada awal shift sebelum bekerja tentang Standard Operational Procedure (SOP) agar tidak terjadi defect core renggang :

1. Pemasangan gum tape lebih teliti agar veneer tidak terlepas.

2. Perputaran roll harus standar atau lambat agar veneer tidak pecah.

3. Penyusunan veneer agar lebih hatihati supaya tidak pecah.

\section{DAFTAR PUSTAKA}

Assauri, Sofjan. (1998). "Manajemen Operasi dan Produksi”. Jakarta : LP.FE UI.

Binus (2007). Landasan Teori. di akses http://library.binus.ac.id/eColls/eThesisdo c/Bab2/2007-3-00456TI\%20Bab\%202.pdf

Gaspersz, Vincent. (2001). "Total Quality Management”. Jakarta : PT. Gramedia Pustaka Utama.

Gaspersz, Vincent. (2002). "Pedoman Implementasi Program Six Sigma”. Jakarta: PT. Gramedia Pustaka Utama.

Gaspersz, Vincent (2005). "Sistem Manajemen Kinerja Terintegrasi Balanced Scorecard Dengan Six Sigma Untuk Organisasi
Bisnis dan Pemerintah". Jakarta : PT. Gramedia Pustaka Utama.

Gaspersz, Vincent (2007). "Lean Six Sigma for Manufacturing and Service Industries ". Jakarta : PT. Gramedia Pustaka.

Kusumawati Aulia dan Lailatul Fitriyeni. (2017).

"Pengendalian Kualitas Proses

Pengemasan Gula Dengan Metode Six Sigma". Jurnal Sistem dan Manajemen Industri Vol 1 No 1 hlm 43-48.

Nasution, M.N (2001). "Total Quality Manajement". Jakarta : Ghalia Indonesia.

Pande, S. Peter, (2002). "The Six Sigma Way Handbook". Bagaimana GE, Motorola dan Perusahaan Terkenal Lainnya. Yogyakarta : ANDI.

Reksohadiprodjo, Sukanto (2000). "Manajemen Produksi". Yogyakarta : BPFE

Supriyadi, Gina Ramayanti, Alex Chandra Roberto (2017). "Analisis Kualitas Produk dengan Pendekatan Six Sigma”. Prosiding SNTI dan SATELIT 2017 (pp. D7-13). Malang : Jurusan Teknik Industri Universitas Brawijaya.

Wardhana, W, Harsono, A, Liansari, G.P. (2015). "Implementasi Perbaikan Kualitas Menggunakan Metode Six Sigma Untuk Mengurangi Jumlah Cacat Produk Sajadah Pada Perusahaan PT. Pondok Tekstil Kreasindo". Bandung. Jurnal Teknik Industri. Vol 3 No 1 hlm 85-96.

Wignjoesoebroto, Sritomo (2003). "Pengantar Teknik dan Manajemen Industri” Surabaya : Guna Widya 